\title{
Ingested foreign body causing a silent perforation of the bowel
}

\author{
Hidde M Kroon 주, 1,2,3 Dean Mullen²
}

${ }^{1}$ Department of Surgery, Royal Adelaide Hospital, Adelaide, South Australia, Australia ${ }^{2}$ Department of Surgery, Flinders Medical Centre, Adelaide, South Australia, Australia

${ }^{3}$ Faculty of Health and Medical Sciences, University of Adelaide, Adelaide, South Australia, Australia

\section{Correspondence to \\ Dr Hidde M Kroon;}

hmkroon@hotmail.com

Accepted 10 December 2020

\section{DESCRIPTION}

In case of ingestion, it is estimated that $80 \%$ of foreign bodies pass through the gastrointestinal tract asymptomatically, while endoscopic removal is required in approximately 20\%. ${ }^{1}$ Perforation, mostly in case of sharp foreign bodies, occurs in less than $1 \%$ and can be dangerous, potentially leading to peritonitis and sepsis. ${ }^{12}$ Sometimes, a foreign body migrates asymptomatically into the abdominal cavity by eroding through the bowel wall without causing leakage of bowel contents. ${ }^{3}{ }^{4}$ Most foreign bodies causing a so-called silent perforation are diagnosed as incidental finding on imaging, with incidences rising due to increased use of imaging modalities such as CT scans. Optimal management of asymptomatic abdominal foreign bodies, conservative or surgical removal, is challenging and has to be determined on individual basis.

A 64-year-old man, with a history of colon cancer, for which he had undergone a laparoscopic-assisted right hemicolectomy 3 years prior, was referred to the Emergency Department by the radiologist after an incidental finding on his annual colon cancer follow-up abdominal CT scan. No recurrent disease was seen on this scan, but it did show left-sided mesenteric stranding encapsulating a radiopaque object piercing into the abdominal wall right of the umbilicus (figure 1). No free air or free fluid was visualised.

The patient recalled eating fish off the bone during vacation weeks prior, and it was therefore thought that the object identified on the CT scan could be a foreign body that had migrated through the wall of the intestine into the abdominal cavity. The patient denied abdominal pain or discomfort and had not experienced changes in his bowel habits. He was afebrile, normotensive and normocardic and all his blood results, including $\mathrm{C}$ reactive protein, white cell count and haemoglobin, were within normal range. On
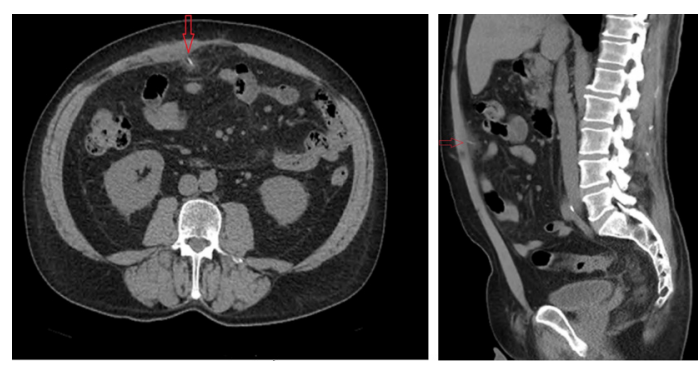

Figure 1 Transverse and sagittal view of CT scan showing the intra-abdominal foreign body with surrounding inflammation, piercing into the abdominal wall right of the umbilicus.

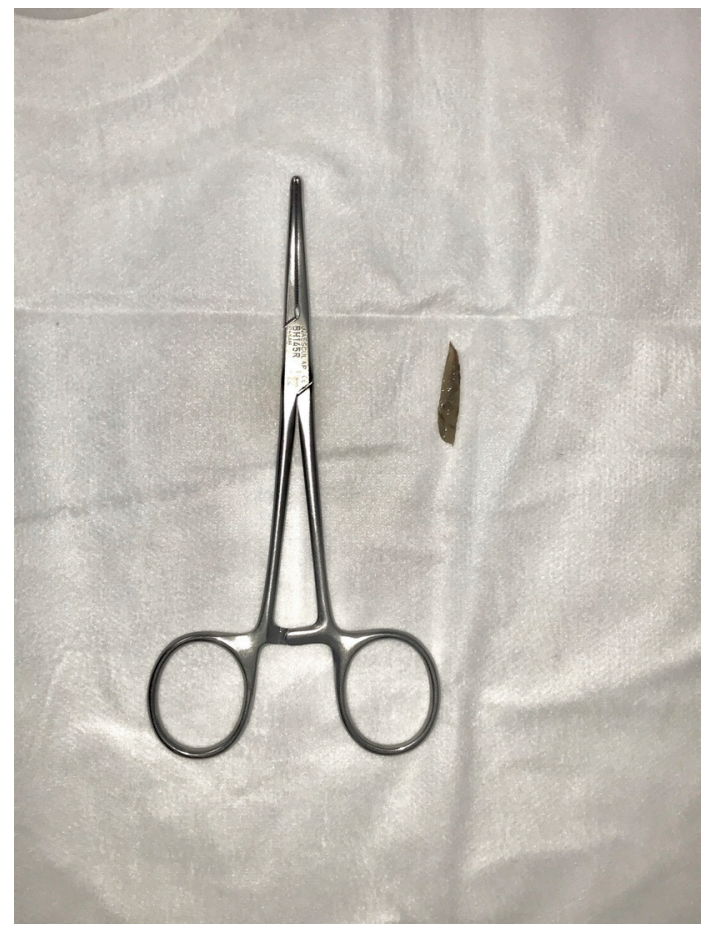

Figure 2 The fish bone pictured next to an artery forceps following removal from the abdominal cavity during the diagnostic laparoscopy.

physical examination, however, he had mild abdominal guarding with a mass palpable on the right side.

In view of a possible early peritonitis caused by a bowel perforation, a diagnostic laparoscopy was performed, during which an omentum-encapsulated foreign body was identified, piercing into the anterior abdominal wall on the right by several millimetres. Adhesiolysis allowed removal of the object; a 3

\section{Patient's perspective}

I would like to express my concern about the in general unknown potential dangers of accidental swallowing of bones or other small sharp objects that may be mixed into our food.

In my situation, I did understand the pros and cons for both the surgical treatment to remove the foreign body, as well as for the conservative treatment option. I chose for surgery because of the uncertainty of what could happen if I had chosen for conservative treatment. I hope my case will help surgeons and other medical specialists to decide what best management is for their patient when they are confronted with a similar patient. 


\section{Learning points}

- A silent perforation of the bowel, during which a foreign body migrates into the abdominal cavity by eroding through the bowel wall without causing symptoms, is rare.

- Most foreign bodies causing a silent perforation are diagnosed as incidental finding, with incidences rising due to the increased use of imaging modalities.

- Optimal management of these asymptomatic abdominal foreign bodies is challenging and has to be determined on individual basis.

$\mathrm{cm}$-long fish bone (figure 2). No bowel was found in the vicinity of the foreign body and no perforation or previous perforation site could be identified during laparoscopic examination of the bowel loops. No free fluid or pus were found either, after which the surgery was terminated.

The patient could be discharged the same day and no complications occurred 30 days postoperatively.
Twitter Hidde M Kroon @hiddekroon

Contributors DM and HMK both provided care for the patient described. HMK and DM both initiated writing the manuscript. HMK prepared the first version of the manuscript, and DM revised.

Funding The authors have not declared a specific grant for this research from any funding agency in the public, commercial or not-for-profit sectors.

Competing interests None declared.

Patient consent for publication Obtained.

Provenance and peer review Not commissioned; externally peer reviewed.

\section{ORCID iD}

Hidde M Kroon http://orcid.org/0000-0002-8923-7527

\section{REFERENCES}

1 Ambe P, Weber SA, Schauer M, et al. Swallowed foreign bodies in adults. Dtsch Arztebl Int 2012;109:869-75.

2 Pinero Madrona A, Fernández Hernández JA, Carrasco Prats M, et al. Intestinal perforation by foreign bodies. Eur J Surg 2000;166:307-9.

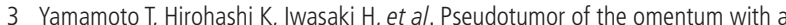
fishbone nucleus. J Gastroenterol Hepatol 2007;22:597-600.

4 Almoudarisa AM CA, Kaneriaa S, Jiyada Z. Fish bone perforation mimicking acute appendicitis. J Med Cases 2011;2:296-9. doi:10.4021/jmc151w

Copyright 2020 BMJ Publishing Group. All rights reserved. For permission to reuse any of this content visit

https://www.bmj.com/company/products-services/rights-and-licensing/permissions/

BMJ Case Report Fellows may re-use this article for personal use and teaching without any further permission.

Become a Fellow of BMJ Case Reports today and you can:

- Submit as many cases as you like

- Enjoy fast sympathetic peer review and rapid publication of accepted articles

- Access all the published articles

Re-use any of the published material for personal use and teaching without further permission

Customer Service

If you have any further queries about your subscription, please contact our customer services team on +44 (0) 2071111105 or via email at support@bmj.com.

Visit casereports.bmj.com for more articles like this and to become a Fellow 